\title{
Hubungan Antara Sikap dengan Perilaku Personal Hygiene Menstruasi Siswi SMA Budi Utomo Jombang
}

\author{
Eka Tyas As Sidiqiah, Siti Nurrochmah*, Farah Paramita \\ Universitas Negeri Malang, Jl. Semarang No. 5 Malang, Jawa Timur, Indonesia \\ *Penulis korespondensi, Surel: siti.nurrochmah.fik@um.ac.id
}

Paper received: 3-1-2022; revised: 21-1-2022; accepted: 28-1-2022

\begin{abstract}
Sexual and reproductive health education is considered taboo to be given to adolescents, as a result, many myths and bad perceptions are spread regarding menstruation. The results of interviews with Budi Utomo High School students, it was found that 6 out of 10 students' behavior personal hygiene had poor. Self-care during menstruation is influenced by factors, biological, cultural, environmental, social values, knowledge, and perceptions. This study aims to determine the relationship between student attitudes towards behavior personal hygiene menstrual. The design of this research is analytic observational with an approach cross-sectional. The research population is 1.374 students of SMA Budi Utomo Jombang with a total sample of 95 respondents who were taken using the technique Quota Sampling. Data was collected by distributing questionnaires in the online form of Google forms. The results showed that most respondents had good attitudes $60(63 \%)$ and behavior personal hygiene good menstrual73 $(77 \%)$. The results of the bivariate analysis using the test chisquare obtained the attitudes and behavior of personal hygiene menstrual ( $p$-value 0.050). The study concludes that there is a significant relationship between attitudes towards behavior for personal hygiene menstrual students at SMA Budi Utomo Jombang.
\end{abstract}

Keywords: personal hygiene menstruation; attitude; adolescent girl

\begin{abstract}
Abstrak
Pendidikan kesehatan seksual dan reproduksi dianggap tabu untuk diberikan pada remaja, akibatnya banyak tersebar mitos dan persepsi buruk terkait menstruasi. Hasil wawancara kepada siswi SMA Budi Utomo, ditemukan 6 dari 10 orang siswi berperilaku personal hygiene yang buruk. Perawatan diri saat menstruasi dipengaruhi oleh faktor, biologis, kebudayaan, lingkungan, nilai sosial, pengetahuan dan persepsi. Penelitian ini bertujuan untuk mengetahui hubungan antara sikap siswi terhadap perilaku personal hygiene menstruasi. Rancangan penelitian ini adalah observasional analitik dengan pendekatan cross sectional. Populasi penelitian yaitu siswi SMA Budi Utomo Jombang sebanyak 1.374 siswi dengan jumlah sampel penelitian sebanyak 95 responden yang diambil menggunakan teknik Quota Sampling. Pengumpulan data dilakukan dengan menyebarkan kuesioner secara online berupa Google form. Hasil penelitian menunjukkan mayoritas responden memiliki sikap baik 60 (63\%) dan perilaku personal hygiene menstruasi baik 73 (77\%). Hasil analisis bivariat menggunakan uji chi square memperoleh sikap dan perilaku personal hygiene menstruasi ( $p$-value 0.050). Kesimpulan penelitian yaitu terdapat hubungan siginifikan antara sikap terhadap perilaku personal hygiene menstruasi siswi SMA Budi Utomo Jombang.
\end{abstract}

Kata kunci: personal hygiene menstruasi; sikap; remaja putri

\section{Pendahuluan}

Pendidikan kesehatan seksual dan reproduksi kerap kali dianggap tabu untuk diberikan pada remaja, sedangkan pertumbuhan dan perkembangan pada remaja berlangsung dalam waktu relatif cepat baik secara fisik maupun mental sehingga mampu menjalankan fungsi proses reproduksinya (Prijatni \& Rahayu, 2016; Riyadi, 2016). Menurut WHO dan Menteri Kesehatan RI, remaja merupakan penduduk dengan rentang usia 10-19 tahun serta BKKBN menyatakan rentang usia remaja adalah 10-24 tahun dan belum menikah. Sekitar 18\% atau 1,2 
miliar penduduk dari total populasi dunia dikuasai oleh kelompok remaja berusia 10-19 tahun dan di Indonesia remaja merupakan kelompok paling besar yaitu sekitar 45,3 juta atau 17\% dari total penduduk (Badan Pusat Statistik (BPS), 2020; Kementerian Kesehatan RI, 2015). Tercatat jumlah remaja di Jawa Timur mencapai 6,1 juta jiwa atau sekitar 15,65\% dari jumlah penduduk Jawa Timur. Menurut kelompok umur, jumlah terbesar berada pada remaja awal (11-15 tahun) yaitu sebanyak 49,77\%, remaja menengah (16-18 tahun) sebanyak 30,36\% dan kelompok umur remaja akhir (18-19 tahun) yaitu 19,87\% (Badan Pusat Statistika (BPS) Provinsi Jawa Timur, 2016). Menurut data Badan Pusat Statistik Kabupaten Jombang (2019: 64), remaja berusia 10-14 tahun berjumlah 108.909 jiwa, sedangkan remaja kelompok umur 15-19 tahun sebanyak 109.206 jiwa (Badan Pusat Statistika (BPS) Kabupaten Jombang, 2019).

Salah satu tanda pubertas yang menandai masa peralihan seorang perempuan dari anakanak ke dewasa yaitu datangnya menstruasi akibat luruhnya dinding rahim (endometrium) yang sudah menebal setelah 14 hari dari masa ovulasi karena tidak adanya pembuahan pada sel telur oleh sperma (Pudiastuti, 2012; Sinaga dkk., 2017). Merujuk data Survei Demografi Kesehatan Reproduksi Remaja Indonesia Tahun 2017, diketahui 26\% wanita mengalami menarche pada umur 12 tahun, 28\% pada umur 13 tahun dan 23\% pada umur 14 tahun (Badan Kependudukan dan Keluarga Berencana Nasional (BKKBN), Badan Pusat Statistik (BPS), Kementerian Kesehatan RI (Kemenkes RI), \& ICF International, 2018). Menariknya terdapat fakta responden wanita mengalami haid pertamanya pada usia 10-11 tahun sebesar 9\%, seiring dengan pertumbuhan dan perkembangan remaja dikhawatirkan bisa menimbulkan berbagai kesempatan dan resiko gangguan atau masalah pada kesehatan reproduksinya, seperti Infeksi Saluran Reproduksi (ISR), Infeksi Menular Seksual (IMS) dan HIV-AIDS (Harnani, Marlina, \& Kursani, 2015).

Pada tahun 2016, WHO menyatakan jumlah kasus baru pada Infeksi Saluran reproduksi (ISR) mencapai lebih dari 1 juta kasus setiap harinya, sehingga terhitung lebih dari 376 juta kasus baru setiap tahunnya. Kelompok usia remaja termasuk penyumbang kasus Infeksi Saluran Reproduksi (ISR) tertinggi di dunia yaitu sebesar 35-42\% dan 27-33\% pada dewasa awal (WHO, 2018). Infeksi Saluran Reproduksi (ISR) diakibatkan oleh organisme yang biasa hidup atau masuk dalam saluran reproduksi atau akibat prosedur medis dan personal hygiene yang buruk seperti penggunaan pembalut menstruasi yang tidak bersih, kebersihan seksual serta cara membersihkan vagina yang buruk (Sharma \& Sheoran, 2015).

Indonesia sebagai salah satu Negara daerah tropis di Asia Tenggara, membuat tubuh jadi lebih rentan untuk berkeringat dan membuat daerah tubuh yang tertutup serta berlipat termasuk organ reproduksi menjadi lebih lembab, sehingga dapat memicu timbulnya ISR. Data yang diperoleh dari Badan Pusat Statistik (BPS) dan Bappenas pada tahun 2010 menunjukkan bahwa mayoritas remaja Indonesia yang mencapai 63 juta jiwa rentan terhadap perilaku tidak sehat terhadap kondisi kebersihan organ reproduksi saat menstruasi (Irianto, 2014; Pawesti, 2015). Menurut data BKKBN tahun 2015 bahwa remaja sangat beresiko tinggi terhadap gangguan kesehatan reproduksi karena pengetahuan mengenai fungsi dan cara merawat organ reproduksi masih sangat rendah yaitu hanya 19,5\% (Ernawati, Asrina, \& Suharni, 2019).

Kuman berupa jamur, bakteri, parasit maupun virus dapat menimbulkan vagina rentan pada infeksi akibat batas antara uretra dan anus sangat sempit sehingga mudah untuk masuk ke dalam liang vagina (Ernawati dkk., 2019). Salah satu upaya mencegah penyakit atau gangguan pada saat menstruasi yaitu membiasakan untuk berperilaku higienis atau upaya 
penyehatan guna memelihara kebersihan dan kesehatan seseorang saat menstruasi (Hastuti, Dewi, \& Pramana, 2019). Perilaku perawatan hygiene menstruasi yang kurang salah satunya adalah tidak mencuci tangan sebelum dan sesudah mengganti pembalut serta frekuensi penggantian pembalut [16]. Perawatan diri saat menstruasi dapat dipengaruhi berbagai faktor antara lain yaitu biologis, kebudayaan, lingkungan, nilai-nilai sosial, pengetahuan dan persepsi terhadap perawatan diri (Hastuti dkk., 2019; Kristanti \& Sebtalesy, 2019).

Masih banyak tersebarnya persepsi dan mitos buruk berkaitan dengan menstruasi di kalangan masyarakat akibat minimnya pengetahuan dan wawasan pada masyarakat sehingga timbul pola pikir yang mengada-ada (Sinaga dkk., 2017). Infeksi pada vagina ini setiap tahunnya menyerang perempuan di seluruh dunia hampir mencapai 10-15\% dari 100 juta perempuan yang dapat disebabkan oleh cara merawat daerah organ genitalia eksterna yang tidak benar (Putri \& Setianingsih, 2016). Sikap negatif akan berdampak terhadap perilaku personal hygiene seseorang, seperti halnya kurang memperhatikan kebersihan pada organ genetalia eksternanya. Remaja yang memiliki pemahaman pada personal hygiene menstruasi akan cenderung memiliki kesadaran untuk melakukan tindakan positif saat mereka menstruasi, namun sikap ini dapat berlanjut untuk mendorong perilaku atau berhenti pada sikap saja (Hastuti dkk., 2019; Notoatmodjo, 2012; Palupi, Pristya, \& Novirsa, 2020). Oleh karena itu, sangat penting bagi remaja putri mendapatkan pendidikan kesehatan reproduksi sedini mungkin, salah satunya terkait personal hygiene menstruasi. Hal ini agar remaja memiliki pengetahuan yang benar untuk bekal saat dewasa serta diharapkan dapat bertanggung jawab pada keputusan dalam pengambilan sikap dan tingkah lakunya terkait cara perawatan diri pada saat menstruasi (Irianto, 2014; Riyadi, 2016).

Berdasarkan hasil wawancara dari siswi SMA Budi Utomo, diketahui bahwa 5 dari 10 orang siswi masih menggunakan pembalut kain saat menstruasi. Dan 6 dari 10 orang siswi diketahui berperilaku personal hygiene yang buruk, yaitu malas mengganti pembalut. Selain itu, frekuensi pembelajaran dan kegiatan ekstrakurikuler berlangsung lebih lama dari pagi hingga sore, disusul dengan kegiatan pengajian di malam hari. Hal ini akan mempengaruhi perilaku personal hygiene remaja putri saat menstruasi, seperti frekuensi penggantian pembalut hanya sekali sehari. Namun, sudah seharusnya remaja wanita membekali dirinya sejak dari rumah untuk berperilaku yang baik saat menstruasi di mana pun.

Berdasarkan hasil penelitian yang dilakukan Winerungan, Esther dan Ferdinand tahun 2013 di kota Manado, menyatakan remaja putri yang memiliki pengetahuan terkait kebersihan diri saat menstruasi dengan kategori baik berjumlah 14 responden $(8,4 \%)$, cukup berjumlah 74 responden $(44,3 \%)$ dan kategori kurang berjumlah 79 responden $(47,3 \%)$ (Winerungan, Hutagaol, \& Wowiling, 2013). Hasil laporan penelitian yang dilakukan oleh Putri \& Setianingsih (2016) didapatkan bahwa sikap personal hygiene menstruasi dengan kategori baik berjumlah 20 siswi (19,6\%), sedangkan kategori kurang berjumlah 82 siswi $(80,4 \%)$ (Putri \& Setianingsih, 2016). Dari latar belakang masalah yang telah dipaparkan di atas dan mengacu pada hasil wawancara dan didukung hasil penelitian terdahulu, peneliti merasa tertarik mengkaji masalah hubungan pengetahuan dan sikap dengan perilaku personal hygiene menstruasi pada siswi di SMA Budi Utomo Jombang. 


\section{Metode}

Penelitian ini adalah penelitian kuantitatif dengan rancangan observasional analitik menggunakan pendekatan cross sectional. Jenis data penelitian ini memanfaatkan data primer yang diperoleh langsung dari responden melalui kuesioner. Penelitian ini dilaksanakan di SMA Budi Utomo Jombang pada bulan April hingga bulan Mei 2021. Adapun populasi penelitian adalah siswi SMA Budi Utomo Jombang berjumlah 1.374 siswi dengan jumlah sampel penelitian yaitu 95 orang yang diperoleh melalui perhitungan sampel menggunakan rumus Lemeshow dan menambahkan 10\% sampel dari jumlah sampel yang telah dihitung. Teknik sampling yang digunakan ialah Quota Sampling yang memenuhi kriteria inklusi: 1) Siswi yang bersedia mengikuti penelitian dan mengisi informed consent, 2) Siswi yang sudah mengalami menstruasi, 3) Siswi yang telah berusia $\geq 17$ tahun, 4) Siswi yang memiliki akses internet yang baik serta kriteria eksklusi: 1) Siswi yang belum mengalami menstruasi, 2) Siswi yang tidak bisa mengisi formulir kuesioner karena akses internet yang buruk.

Instrumen pada penelitian ini menggunakan kuesioner yang akan disebarkan secara online berupa Google form melalui whatsapp tiap grup kelas. Penggunaan kuesioner ini telah melalui validasi menggunakan uji Pearson Product Moment serta reliabel dengan perhitungan menggunakan rumus Alpha Cronbach. Pengukuran sikap menggunakan pertanyaan berupa skala likert berjumlah 11 pertanyaan dengan hasil validitas keseluruhan pertanyaan valid dan hasil reliabilitas $0,773>0,334$ ( $\mathrm{r}$ tabel). Pengukuran perilaku menggunakan pertanyaan berupa multiple choice berjumlah 10 pertanyaan dengan hasil validitas keseluruhan pertanyaan valid dan hasil reliabilitas $0,529>0,334$ ( $\mathrm{r}$ tabel).

Hasil data penelitian yang diperoleh kemudian dianalisis secara univariat untuk mendeskripsikan tiap variabel menggunakan tabel distribusi frekuensi. Lalu data dianalisis secara bivariat untuk melihat adakah hubungan antara variabel bebas (independen) dan variabel terikat (dependen) menggunakan uji statistik Chi Square dengan bantuan software komputer SPSS 22. Penelitian ini telah lolos kaji etik dan mendapat persetujuan dari Komisi Etik Penelitian Kesehatan Politeknik Kesehatan Kemenkes Malang dengan nomor 045/KEPKPOLKESMA/2021.

\section{Hasil dan Pembahasan}

Hasil penelitian yang dianalisis secara univariat dan bivariat adalah sebagai berikut:

\subsection{Analisis Univariat}

\subsubsection{Karakterstik Responden}

Tabel 1. Karakteristik Responden Berdasarkan Usia, Usia Menarche dan Jenis Pembalut

\begin{tabular}{llll}
\hline Kategori & Sub Kategori & Jumlah & Persentase \\
\hline \multirow{3}{*}{ Usia } & 17 tahun & 66 & $69 \%$ \\
& 18 tahun & 20 & $21 \%$ \\
& 19 tahun & 9 & $9 \%$ \\
\hline \multirow{3}{*}{ Usia menarche } & $<12$ tahun & 10 & $11 \%$ \\
& $12-13$ tahun & 49 & $52 \%$ \\
& $\geq 14$ tahun & 36 & $38 \%$ \\
\hline \multirow{2}{*}{ Jenis Pembalut } & Pembalut sekali pakai & 77 & $81 \%$ \\
& Pembalut kain/handuk (menstrual pad) & 18 & $19 \%$ \\
\hline
\end{tabular}


Karakteristik responden pada Tabel 1. diatas menggambarkan bahwa dari total responden sebanyak 95 orang berdasarkan kategori usia didominasi oleh responden yang berusia 17 tahun, yaitu sebanyak 66 responden (69\%), 18 tahun sebanyak 20 responden (21\%) dan paling sedikit berusia 19 tahun sebanyak 9 responden (9\%). Karakteristik responden berdasarkan kategori usia menarche (usia pertama kali menstruasi) dalam penelitian ini mayoritas responden berusia 12-13 tahun sebanyak 49 responden (52\%), $\geq 14$ tahun sebanyak 36 responden (38\%) dan paling sedikit berusia $<12$ tahun sebanyak 10 responden (11\%). Karakteristik responden berdasarkan kategori jenis pembalut yang digunakan mayoritas responden menggunakan pembalut sekali pakai sebanyak 77 responden (82\%) dan paling sedikit menggunakan pembalut kain/handuk (menstrual pad) sebanyak 18 responden (19\%).

\subsubsection{Sikap}

Tabel 2. Sikap Responden Tentang Personal Hygiene Menstruasi

\begin{tabular}{llll}
\hline Variabel & Kategori & Jumlah & Persentase \\
\hline \multirow{2}{*}{ Sikap } & Baik & 60 & $63 \%$ \\
& Buruk & 35 & $37 \%$ \\
\hline Total & & 95 & $100 \%$ \\
\hline
\end{tabular}

Karakteristik responden pada Tabel 3. diatas menggambarkan bahwa sikap responden terhadap personal hygiene dari total responden didominasi oleh sikap baik sebanyak 60 responden (63\%) dan sikap buruk sebanyak 35 responden (37\%). Sehingga, dapat dikatakan bahwa mayoritas responden mayoritas penelitian ini sebanyak 60 responden (63\%) memiliki sikap yang baik tentang personal hygiene menstruasi. Hasil penelitian ini sejalan dengan Suryani (2019) pada penelitiannya ia menyatakan bahwa jumlah responden yang memiliki sikap baik sebanyak 47 responden (57\%) dan sikap buruk sebesar 35 responden (43\%) terkait personal hygiene saat menstruasinya (Suryani, 2019).

Sikap merupakan respon atau tanggapan terhadap stimulus atau objek yang sifatnya masih tertutup dari yang dipelajarinya dan bisa menentukan tanggapannya terhadap situasi tertentu (Yakina, Adi, \& Ariwinanti, 2020). Seseorang yang memiliki sikap baik dibentuk melalui emosi, pikiran, keyakinan dan pengetahuan pada dirinya. Sikap merupakan kemauan atau kesiapan (predisposisi) untuk melakukan tindakan, bukan pelaksanaan motif tertentu (Notoatmodjo, 2012). Seiringan dengan mudahnya remaja memperoleh banyak informasi dari berbagai media atau kegiatan penyuluhan dapat meningkatkan intuisi dan ilmu pada dirinya, hal tersebut bisa menjadi alasan untuk terbentuknya sikap seseorang. Setelah itu, remaja yang telah menyerap ilmu dengan baik, kemudian ia akan berusaha menerapkan dan membiasakan sikap tersebut pada dirinya (Pythagoras, 2017).

\subsubsection{Perilaku Personal Hygiene Menstruasi}

Tabel 3. Perilaku Personal Hygiene Menstruasi Responden

\begin{tabular}{llll}
\hline Variabel & Kategori & Jumlah & Persentase \\
\hline Perilaku Personal & Baik & 73 & $77 \%$ \\
Hygiene Menstruasi & Buruk & 22 & $23 \%$ \\
\hline Total & & 95 & $100 \%$ \\
\hline
\end{tabular}


Karakteristik responden pada Tabel 4. diatas menggambarkan bahwa perilaku personal hygiene menstruasi dari total responden didominasi oleh perilaku personal hygiene menstruasi baik sebanyak 73 responden (77\%) dan perilaku personal hygiene menstruasi buruk sebanyak 22 responden $(23 \%)$. Sehingga, dapat dikatakan bahwa mayoritas responden penelitian ini sebanyak 73 responden (77\%) memiliki perilaku personal hygiene menstruasi yang baik. Hasil penelitian ini didukung oleh Andani (2019) pada penelitiannya yang menyatakan bahwa mayoritas responden memiliki perilaku baik pada personal hygiene menstruasi sebanyak 62 orang $(79.5 \%)$ dan sedikit responden yang memiliki perilaku personal hygiene menstruasi buruk sebanyak 16 orang (20.5\%) (Andani, 2019).

Personal hygiene menstruasi merupakan perawatan simpatik, emosional dan kebersihan selama menstruasi utamanya terkait area genital, pembalut wanita, kebersihan diri, pola makan dan olahraga (Clement, 2012). Perilaku seseorang dapat terbentuk melalui tahap proses perubahan dari pengetahuan (know), sikap (attitude) dan perilaku (practice). Pengetahuan remaja mengenai masalah kesehatan pada reproduksi akan mempengaruhi sikapnya, apabila pengetahuan yang dimiliki baik akan membentuk sikap yang baik pula. Seseorang yang sudah memiliki pengetahuan dan sikap yang baik dapat mengarahkan perilaku seseorang pada hal yang baik begitu pun sebaliknya (Kiswanto, Wardani, \& Hapsari, 2019; Pythagoras, 2017). Kurangnya pengetahuan dan sikap tentang personal higiene menstruasi menimbulkan perilaku upaya pencegahan terhadap gangguan kesehatan reproduksi sulit diterapkan. Penerapan personal hygiene menstruasi yang kurang akan memudahkan timbulnya gangguan kesehatan reproduksi (Jasmine, Rosida, \& Marlinae, 2016).

\subsection{Analisis Bivariat}

\subsubsection{Hubungan antara Sikap dan Perilaku Personal Hygiene Menstruasi}

Tabel 4. Hubungan Antara Sikap dan Perilaku Personal Hygiene Menstruasi Siswi di SMA Budi Utomo Jombang

\begin{tabular}{|c|c|c|c|c|c|c|c|c|}
\hline \multirow{3}{*}{ Sikap } & \multicolumn{4}{|c|}{ Perilaku personal hygiene menstruasi } & \multirow{2}{*}{\multicolumn{2}{|c|}{ Total }} & \multirow{3}{*}{ x2 hitung } & \multirow{3}{*}{$p$ value } \\
\hline & \multicolumn{2}{|c|}{ Baik } & \multicolumn{2}{|c|}{ Buruk } & & & & \\
\hline & $\mathrm{n}$ & $\%$ & $\mathrm{n}$ & $\%$ & $\mathrm{n}$ & $\%$ & & \\
\hline Baik & 50 & 52.6 & 10 & 10.5 & 60 & 63.2 & \multirow{3}{*}{3.856} & \multirow{3}{*}{0.050} \\
\hline Buruk & 23 & 24.2 & 12 & 12.6 & 35 & 36.8 & & \\
\hline Total & 73 & 76.8 & 22 & 23.2 & 95 & 100 & & \\
\hline
\end{tabular}

Hasil analisis bivariat pada Tabel 6. diatas menunjukkan bahwa sejumlah 50 responden (52.6\%) memiliki sikap baik disertai perilaku personal hygiene menstruasi baik dan sikap baik disertai perilaku personal hygiene menstruasi buruk sebanyak 10 responden (10.5\%). Sedangkan responden yang memiliki sikap buruk disertai perilaku personal hygiene menstruasi baik sebanyak 23 responden (24.2\%) dan sikap buruk disertai perilaku personal hygiene menstruasi buruk sebanyak 12 responden (12.6\%). Hasil analisis bivariat menggunakan uji statistik Chi Square pada penelitian didapatkan hasil $3.856>3.841(\mathrm{dk}=1)$ dan p-value $0.050<0,05(\alpha)$, maka dapat disimpulkan bahwa adanya hubungan antara sikap dan perilaku Personal hygiene menstruasi.

Pertumbuhan dan perkembangan pada remaja berlangsung dalam waktu relatif cepat baik secara fisik maupun mental sehingga menyebabkan remaja sudah mampu melakukan 
fungsi proses reproduksinya, seiringan dengan hal tesebut perlu adanya dukungan untuk membentuk sikap yang baik terutama menanggapi kondisi sebagai perempuan yang akan mengalami menstruasi (Ernawati, 2013; Prijatni \& Rahayu, 2016). Sikap negatif pada remaja akan berdampak terhadap perilaku terutama terkait personal hygiene menstruasinya, remaja yang telah mengetahui tentang personal hygiene menstruasi akan memiliki bekal yang positif saat mereka menstruasi (Hastuti dkk., 2019; Palupi dkk., 2020).

Pada penelitian ditemukan sebanyak 50 responden (52.6\%) memiliki sikap baik disertai perilaku personal hygiene baik. Hasil penelitian ini didukung oleh penelitian Lestariningsih (2015) yang menyatakan bahwa ada hubungan antara sikap dengan praktik personal hygiene menstruasi dengan nilai $\mathrm{p}=0.053$ (Lestariningsih, 2015). Sikap merupakan bentuk lanjutan dari kesadaran dan pemahaman seseorang yang menimbulkan kecenderungan untuk melakukan suatu tindakan serta menggambarkan suka atau tidaknya terhadap objek yang telah diperoleh dari pengalaman sendiri atau orang lain (Notoatmodjo, 2012)].

Sikap dapat berlanjut untuk mendorong perilaku tetapi mungkin juga tidak, atau berhenti pada sikap saja (Notoatmodjo, 2012). Dari hasil penelitian yang dilakukan masih ditemukan responden dengan sikap buruk disertai perilaku buruk sebanyak 12 responden (12.6\%). Peneliti berasumsi hal tersebut disebabkan masih banyak responden yang memiliki kepercayaan, budaya atau mitos seperti penggunaan pembalut sekali pakai sebaiknya dicuci dahulu sebelum dibuang, sedangkan pembalut sekali pakai seharusnya langsung dibuang tanpa perlu dicuci. Notoatmodjo (2012: 198) menyatakan kepercayaan atau budaya yang tersebar di masyarakat bisa mempengaruhi pengetahuan remaja (Notoatmodjo, 2012).

Budaya atau mitos seperti pembalut sekali pakai sebaiknya dicuci dahulu sebelum dibuang telah melekat pada banyak individu, mereka mempercayai bahwa bila tidak mencucinya dahulu akan "diikuti" oleh setan, sedangkan hal tersebut belum terbukti kebenarannya. Namun, apabila seseorang menolak pada kepercayaan, budaya atau mitos yang tidak disertai tanpa adanya kebenaran secara ilmiah memberikan makna bahwa pengetahuan yang dimiliki semakin baik, sehingga secara tak langsung bisa mempengaruhi personal hygiene yang dimiliki (Wahyudi, Asmoro, \& Suarilah, 2018). Suka atau tidaknya seseorang berdasarkan pengalaman sendiri atau orang lain terhadap suatu objek atau peristiwa bisa menggambarkan sikap seseorang. Selain itu, sikap juga dibentuk oleh komponen penting seperti pengetahuan, pikiran, keyakinan dan emosi (Notoatmodjo, 2012)]. Sehingga sikap positif maupun negatif juga bergantung dari pemahaman individu yang akan mendorong individu untuk membentuk perilaku tertentu pada saat dibutuhkan, akan tetapi apabila sikapnya negatif, justru akan mendorong individu menghindari perilaku tersebut (Maulina, 2017).

\section{Simpulan}

Berdasarkan hasil penelitian yang telah dipaparkan, maka dapat diambil kesimpulan yaitu terdapat hubungan yang signifikan antara sikap dan perilaku personal hygiene menstruasi siswi di SMA Budi Utomo Jombang dari hasil uji statistik Chi Square yang memperoleh hasil $3.856>3.841(\mathrm{dk}=1)$ dan p value $=0.050<0,05(\alpha)$. Diharapkan pihak sekolah SMA Budi Utomo Jombang untuk meningkatkan wawasan melalui kegiatan KIE terkait upaya penyehatan perilaku personal hygiene menstruasi, serta siswi bisa aktif mencari informasi terkait personal hygiene dengan bijak dan tidak menerima informasi lainnya yang tidak bisa dipertanggungjawabkan kebenarannya. Diharapkan juga bagi peneliti selanjutnya yang hendak melakukan penelitian dapat mengembangkan penelitian menggunakan variabel 
serupa atau lainnya untuk mengetahui faktor yang dapat mempengaruhi personal hygiene menstruasi.

\section{Daftar Rujukan}

Andani, P. R. (2019). Correlation Between Knowledge and Attitude Toward Personal Menstrual Hygiene Practice Among Adolescents. JPH RECODE, 4(2), 88-98. http://dx.doi.org/10.20473/jphrecode. v4i2.14460

Badan Kependudukan dan Keluarga Berencana Nasional (BKKBN), Badan Pusat Statistik (BPS), Kementerian Kesehatan RI (Kemenkes RI), \& ICF International. (2018). Survei Demografi dan Kesehatan Remaja Indonesia 2017. Jakarta: BKKBN, BPS, Kemenkes RI dan ICF International. Diambil dari https://promkes.net/2018/10/19/laporan-sdki-tahun-2017-kesehatan-reproduksi-remaja/

Badan Pusat Statistik (BPS). (2020). Statistik Indonesia 2020. Jakarta: Badan Pusat Statistik. Diambil dari https://www.bps.go.id/publication/2020/04/29/e9011b3155d45d70823c141f/statistik-indonesia2020.html

Badan Pusat Statistika (BPS) Kabupaten Jombang. (2019). Kabupaten Jombang Dalam Angka 2019. Jombang: Badan Pusat Statistika (BPS) Kabupaten Jombang. Diambil dari https://jombangkab.bps.go.id/publication/2019/08/16/13ed62a0f2f7470798e508f1/kabupaten-jombang-dalam-angka-2019.html

Badan Pusat Statistika (BPS) Provinsi Jawa Timur. (2016). Statistik Remaja Jawa Timur 2015. Surabaya: Badan Pusat Statistik Provinsi Jawa Timur. Diambil dari https://jatim.bps.go.id/publication/2016/06/30/d1fac45b25821d9a73e967c2/statistik-remaja-jawa-timur-2015.html

Clement, I. (2012). Manual of Commcunity Health Nursing. New Delhi: Jaypee Brothers Medical Publishers.

Ernawati, E. Asrina, A. \& Suharni, S. (2019). Pengaruh Metode Diskusi Terhadap Pengetahuan Dan Sikap Tentang Kebersihan Diri (Studi Pada Santriwati Pondok Pesantren Darul Abrar). Seminar Nasional Sinergitas Multidisiplin Ilmu Pengetahuan dan Teknologi (SMIPT), 2, 48-53.

Ernawati, E. (2013). Faktor Determinan Terjadinya Vaginosis Bakterial PadaWanita Usia Subur di Kota Makassar. Jurnal Ilmiah Kesehatan Diagnosis, 3(5), 71-78.

Harnani, Y. Marlina, H. \& Kursani, E. (2015). Teori Kesehatan Reproduksi (Untuk Mahasiswa Ilmu Kesehatan Masyarakat). Sleman: Deepublish.

Hastuti, D, R. K. \& Pramana, R. P. (2019). Studi Kasus Manajemen Kebersihan Menstruasi (MKM) Siswa SD dan SMP di Indonesia. Jakarta: The SMERU Research Institute. Diambil dari http://www.smeru.or.id/sites/default/files/publication/mkm_id_0.pdf

Irianto, K. (2014). Panduan Lengkap Biologi Reproduksi Manusia (Human Reproductive Biology) Untuk Paramedis dan Nonmedis. Bandung: Alfabeta.

Jasmine, I. A. Rosida, L. \& Marlinae, L. (2016). Hubungan Antara Pengetahuan dan Sikap Tentang Personal Higiene dengan Perilaku Pencegahan Penularan Skabies. Jurnal Publikasi Kesehatan Masyarakat Indonesia, 3(1), 7-12. http://dx.doi.org/10.20527/jpkmi.v3i1.2730

Kementerian Kesehatan RI. (2015). Infodatin Kesehatan Reproduksi Remaja. Pusat Data dan Informasi Kementerian Kesehatan RI. Diambil dari https://pusdatin.kemkes.go.id/download.php?file=download/pusdatin/infodatin/infodatin-reproduksi-remaja.pdf

Kiswanto, K. Wardani, H. E. \& Hapsari, A. (2019). Hubungan Pengetahuan dengan Mitra Pria dalam Keluarga Berencana di Desa Klampok, Kecamatan Singosari, Kabupaten Malang. Sport Science and Health, 1(1), 10-13.

Kristanti, L. A. \& Sebtalesy, C. Y. (2019). Kapasitas Orang Tua Terhadap Personal Hygiene Anak Autis. Ponorogo: Uwais Inspirasi Indonesia.

Lestariningsih, S. (2015). Faktor-Faktor Yang Berhubungan Dengan Praktik Higiene Menstruasi. Jurnal Kesehatan Metro Sai Wawai, 8(2), 14-22. http://dx.doi.org/10.26630/jkm.v8i2.174

Maulina, N. (2017). Hubungan Pengetahuan Dan Sikap Remaja Putri Dengan Personal hygiene Saat Menstruasi Pada Siswi Kelas IX DI SMP Negeri 1 Lhokseumawe Tahun 2016. Jurnal Ilmiah Sains, Teknologi, Ekonomi, Sosial dan Budaya, 1(1), 74-79.

Notoatmodjo, S. (2012). Promosi Kesehatan dan Perilaku Kesehatan. Jakarta: PT. Rineka Cipta. 
Palupi, T. D. Pristya, T. Y. R. \& Novirsa, R. (2020). Myths About Menstrual Personal Hygiene Among Female Adolescents. Jurnal Kesehatan Masyarakat Nasional (National Public Health Journal), 15(2), 80-85. https://doi.org/10.21109/kesmas.v15i2.2719

Pawesti, G. C. T. (2015). Pengaruh Metode Multimedia Learning Tentang Perineal Hygiene Terhadap Pengetahuan Dan Sikap Pada Remaja Putri Yang Mengalami Menstruasi di SMP PGRI 1 Pakisaji Kabupaten Malang (University Muhammadiyah Malang). University Muhammadiyah Malang. Diambil dari http://eprints.umm.ac.id/23543/1/jiptummpp-gdl-gitacitrat-40027-2-bab1.pdf

Prijatni, I. \& Rahayu, S. (2016). Modul Bahan Ajar Cetak Kebidanan: Kesehatan Reproduksi dan Keluarga Berencana. Jakarta: Pusat Pendidikan Sumber Daya Manusia Kesehatan.

Pudiastuti, R. D. (2012). Tiga Fase Penting Pada Wanita. Jakarta: PT Elex Media Komputindo.

Putri, N. A. \& Setianingsih, A. (2016). Hubungan Pengetahuan dan Sikap Terhadap Perilaku Personal hygiene Mentruasi. Jurnal Ilmu Kesehatan Masyarakat, 5(1), 62-76. https://doi.org/10.33221/jikm.v5i1.310

Pythagoras, K. C. (2017). Personal Hygiene Remaja Putri Ketika Menstruasi. Jurnal Promkes, 5(1), 13-26. http://dx.doi.org/10.20473/jpk.V5.I1.2017.13-26

Riyadi, A. (2016). Pemenuhan Hak Kesehatan Seksual dan Reproduksi (Annual Report 2015). Jakarta: PKBI.

Sharma, P. \& Sheoran, P. (2015). Screening and Assessment of Knowledge and Expressed Practices Regarding Reproductive Tract Infection among Married and Unmarried Women in Rural Area of Mullana, Ambala, Haryana. International Journal of Science and Research (IJSR), 4(2), 465-470.

Sinaga, E. Saribanon, N. Sa'adah, S. N. Salamah, U. Murti, Y. A. Trisnamiati, A. \& Lorita, S. (2017). Manajemen Kesehatan Menstruasi. Jakarta: Universitas Nasional IWWASH Global One. Diambil dari http://ppi.unas.ac.id/wp-content/uploads/2017/06/Buku-Manajemen-Kesehatan-MenstruasiOke.pdf

Suryani, L. (2019). Faktor-Faktor Yang Mempengaruhi Perilaku Remaja Putri Tentang Personal Hygiene Pada Saat Menstruasi di SMP Negeri 12 Kota Pekanbaru. JOMIS (Journal of Midwifery Science), 3(2), 68-79.

Wahyudi, A. S. Asmoro, C. P. \& Suarilah, I. (2018). Faktor Yang Berhubungan Dengan Personal Hygiene Saat Menstruasi. Jurnal Kesehatan Manarang, 4(2), 104-113. https://doi.org/10.33490/jkm.v4i2.96

WHO. (2018). Report On Global Sexually Transmitted Infections Surveillance 2018. Geneva: WHO. Diambil dari https://apps.who.int/iris/bitstream/handle/10665/277258/9789241565691-eng.pdf?ua=1

Winerungan, E. M. Hutagaol, E. \& Wowiling, F. (2013). Hubungan Pengetahuan Kesehatan Reproduksi Dengan Kejadian Iritasi Vagina Saat Menstruasi Pada Remaja di SMP Negeri 8 Manado. Jurnal Keperawatan, 1(1), 1-6.

Yakina, A. N., Adi, S. \& Ariwinanti, D. (2020). Pengaruh Pendidikan Kesehatan Menggunakan Team Games Tournament (TGT) Terhadap Pengetahuan dan Sikap Cuci Tangan Pakai Sabun Pada Pencegahan Penyakit Diare di Siswa Kelas 5 Sekolah Dasar. Sport Science and Health, 2(2), 145-151. 